\title{
Changing Malaysia's Deradicalisation Programme through Best Practices Learned from Denmark and Morocco
}

\author{
Marina Abdul Majid \\ Senior lecturer, Strategic and Security Analysis Programme \\ Research Centre for History, Politics and International Affairs \\ Faculty of Social Sciences and Humanities \\ National University of Malaysia (UKM) \\ 43600 Bangi, Selangor \\ MALAYSIA \\ Radzween Abdul Razak \\ Postgraduate master's student, Strategic and Security Analysis Programme \\ Research Centre for History, Politics and International Affairs \\ Faculty of Social Sciences and Humanities \\ National University of Malaysia (UKM) \\ 43600 Bangi, Selangor \\ MALAYSIA
}

\begin{abstract}
Returning Daesh foreign terrorist fighters (FTFS) from Syria and Iraq threaten Malaysia's security. Weaknesses in policy and the deradicalisation programme have impeded the Malaysian government's efforts to inhibit the FTF's ideologies and prevent violence. This study aimed to analyse the current implementation of Malaysia's deradicalisation policies and programmes, which can be improved by emulating some of Denmark and Morocco's best practices, for the betterment of Malaysian society. This qualitative study relied on interviews of Malaysian ministries, agencies and experts handling deradicalisation matters. Secondary resources such as journals, books, newspapers and Internet resources were also consulted. The results show that Malaysia needs qualified psychologists specifically trained to change the terrorist mindset as well as establish a post-deradicalisation programme involving families and communities, incorporating non-governmental organisations (NGOs) and private firms to reduce the government's financial burden.
\end{abstract}

Keywords: Daesh, foreign terrorist fighters, deradicalisation, non-governmental organisations, Denmark, Morocco, Malaysia

\section{Introduction}

A terrorist deradicalisation programme is part of a country's counter terrorism strategy. Deradicalisation, for the purpose of this study, comprises "programmes that are generally directed against individuals who have been radical with the aim of re-integrating them into society or at least dissuading them from violence" (United Nations, 2008, p. 5). Such programmes aim to change the radical mindset of terrorists so they can rejoin society. It is implemented in stages and involves different approaches based on the individual's radicalisation level (Feldstein, 2015). The programme also aims to reintegrate ex-terrorist detainees into the community, including Daesh foreign terrorist fighters (FTFS) from Syria and Iraq.

Some scholars tend to compare the deradicalisation programmes of countries within the same geographical region, such as the Southeast Asiannations of Malaysia, Singapore, Indonesia and the Philippines (Kamaruddin, Nordin \& Rahman, 2017; Mabborang, 2019; Suratman, 2017; Walanda, 2020). Singapore, for instance, implements an exemplary Countering Violent Extremism (CVE) programme rather than a more complex deradicalisation programme (Kamaruddin et al., 2017; Mabborang, 2019; Suratman, 2017; Walanda, 2020). However, with few terrorist attacks so far, Singapore's CVE programme has not been tested fully, especially in dealing with hardcore terrorists (Suratman, 2017). Government expertise and funds dedicated to deradicalisation are inadequate and will soon be depleted. 
Consequently, Singapore and Indonesia involve non-governmental organisations (NGOs)in assisting with their CVE or deradicalisation programme because of limited funding and human resources for training (Suratman, 2017; Levenia \& Sciascia, 2020). Suratman (2017) asserted that collaboration with NGOs is a new phenomenon for Southeast Asian countries, which the West has long since leveraged. Going beyond a comparison of deradicalisation programmes in Southeast Asia, Walanda (2020) made a comparison with Denmark, as Southeast Asian nations can learn much from those countries.

Also of interest to this study is Morocco, an African Islamic country whose deradicalisation programme and policies have been praised by the United States (US) (Aziza, 2018, p. 6). Morocco's programme addresses the socioeconomic conditions that breed terrorism by providing adequate housing for the indigent, with dedicated funding and NGO involvement (Aziza, 2018). Moreover, Moroccan media, television and internet preach moderate Islam to counter radical Islamists (Aziza, 2018). Malaysia can learn from Denmark and Morocco, going beyond regional neighbours such as Indonesia and the Philippines who are still refining their programmes. A comparison of Denmark and Morocco's deradicalisation programme with Malaysia's can contribute to terrorism and deradicalisation studies; to the best of our knowledge, such a comparison has not been undertaken before.

Therefore, this study aimed to analyse Malaysia's current implementation of deradicalisation policies and programmes for their improvement by emulating the relevant best practices of Denmark and Morocco, thereby bettering Malaysian society. It was hoped that new insights and ideas would be obtained from Denmark and Morocco's programmes and policies, beyond information already known among Southeast Asian countries.

\section{Overview of Malaysia's Prevention of Terrorism Act 2015 (POTA) Integrated Deradicalisation Programme}

In Malaysia, the Royal Malaysian Police (RMP), the Malaysian Prison Department and the Ministry of Home Affairs (MOHA) are the main agencies responsible for managing the deradicalisation programme (RMP, 2019). The government introduced the Prevention of Terrorism Act (POTA) 2015 on 1 September 2015, prescribing preventive measures and covering offences committed within and outside the Malaysian borders, including those committed by the Malaysian Daesh FTFS who fought alongside Daesh in Syria and Iraq (MOHA, 2015). The government decided that POTA 2015 must be drafted in tandem with Article 149 of the Malaysian Federal Constitution, anticipating that it would become a preventive law, where in decision-making power lies with a board instead of an open court (MOHA, 2015). Several safeguards such as consulting a board of advisors for any appeals based on Article 151 of the Federal Constitution were included to protect the rights of detainees. Individuals charged under this law have the right to legal representation before the board of advisors (MOHA, 2015).

In strengthening the provisions of POTA 2015, the Malaysian government introduced the POTA Integrated Deradicalisation Programme, which involves religious experts and officers from various government agencies (MOHA, 2015). The programme module comprises 18 sub-modules and 102 lecture titles on religious syllabi, psychology, safety, citizenship and good values (MOHA, 2015). Besides Bahasa Malaysia, this module has been translated into three foreign languages: English, Arabic and French (MOHA, 2015).

The POTA Integrated Deradicalisation Programme module involves three phases:

A. The first phase is a six-month orientation module, covering the management of documentation, safety and health of detainees to ensure they can adapt to the detention centres and shape their mental and physical endurance to obey the rules and laws (MOHA, 2015).

B. The second phase involves the development of personality, which takes between seven and12 months. It aims to foster positive attitudes among detainees in preparation for their release. The irrespective identities can also be nurtured through the psychological approach provided in this programme. Psychological officers of the Prisons Department of Malaysia conduct interventions for psychopathology, anger management, change of mindset, anti-social personality and spiritual disturbance (MOHA, 2015). This psychological assessment is important because Daesh detainees are capable of making psychological attacks through social media and enlisting new recruits (RMP, 2019).

C. The third phase is linked to the second phase and takes between 13 and 24 months. It aims to provide detainees with self-care, parenting, conflict management and creative thinking skills. Psychopathological tests are conducted for the second time to re-evaluate the psychological status of detainees before release (MOHA, 2015).

There have been significant challenges in Malaysia's deradicalisation programme (Al-Muhammady, personal communication, November 16,2019; Z.M. Zin, personal communication, February 12, 2020). This is because some of the psychologists and guest speakers appointed by various agencies lack the skills to hold the detainees' attention. Z.M. 
Zin (personal communication, February 12, 2020) asserted that these officers were not specifically trained to participate in the terrorist deradicalisation programme and had been transferred from one department to another due to various reasons. This makes the psychological module ineffective, affecting the overall POTA Integrated Deradicalisation Programme (Z.M. Zin, personal communication, February 12, 2020).

\section{Methodology}

This qualitative study involved a comparison of the deradicalisation policies and programmes of the selected countries - Malaysia, Denmark and Morocco.

\subsection{Forms of data}

To gather information about Malaysia's deradicalisation programme, some MOHA and RMP documents were consulted. Further, relevant individuals who are experts and provide advice to the Malaysian government agencies regarding the deradicalisation programme in Malaysia were interviewed,including Dr. Zamihan Mat Zin, Senior Deputy Director, Department of Islamic Development Malaysia (JAKIM), Dr. Ahmad Al-Muhammady, political science lecturer at the International Islamic University of Malaysia (IIUM) and Jasmine Jawhar from the Southeast Asia Regional Centre for Counter-Terrorism (SEARCCT) at the Ministry of Foreign Affairs, Malaysia.

Books, book chapters, journals, newspaper articles and internet materials were also referred to for relevant secondary data on the background of Malaysia, Denmark and Morocco's deradicalisation programmes.

\subsection{Analysis of the data}

The interview and secondary data gathered in this study were subjected to a content analysis and divided into relevant themes. To ensure accuracy of the interview data, the written notes were shared with the interviewees for verification and then deemed fit to be processed and utilised in this study.

\section{Results and Discussion}

\subsection{Challenges in Malaysia's Deradicalisation Programme}

The government's effort to address the issue of terrorism and radicalisation of FTFS can be regarded as successful since the RMP managed to detain those involved before any attacks occurred. This is an achievement of the RMP, in addition to existing laws such as the Security Offenses (Special Measures) Act 2012 (SOSMA), the Prevention of Criminal Act (POCA) 1959 and the POTA 2015 (RMP, 2019). However, despite the RMP's success, there are challenges that must be addressed to ensure the effectiveness of the deradicalisation programme for Daesh militants and FTFS namely:

\section{A. Implementing a Balanced Deradicalisation Approach}

Identifying diverse approaches to counter the radical ideologies of individuals who influence other detainees, including former FTFS, is a major challenge. JAKIM 's representative highlighted the following:

Religious-based deradicalisation programme alone will not be entirely successful and could allow the terrorists and FTF detainees to return to their previous terrorist activities. Therefore, I think a more pragmatic module should be implemented by focusing on the aspects of integration and personal-skills development. A deradicalisation centre has to somehow integrate these skills into their programme with methods that are embedded in their modules to ensure the programme quality and effectiveness. Countries that keep pace with evolving trends have greater success and smaller recidivism rates. Counsellors, religious personnel, prison officers and all involved must be prepared to incorporate various aspects of deradicalisation (Z.M. Zin, personal communication, February 12, 2020).

\section{B. Ensuring Former Detainees Do Not Relapse into Terrorism}

The effectiveness of Malaysia's deradicalisation programme can be evaluated through former detainees' ability to avoid recidivism. In some countries, counselling services are provided to former terrorists, but continuous moral support from the immediate family is also crucial in building confidence among former detainees (Z.M. Zin, personal communication, February 12, 2020).Due to the present challenging environment, former detainees who are marginalised may return to terrorism if not accepted into society.

\section{Exploitation of Digital Technology}

Information communications technology (ICT) advancement has also accelerated Daesh's recruitment of and propaganda dissemination among FTFS and sympathisers through online platforms, as compared to physical 
encounters. This poses a challenge to the deradicalisation programme and managing the FTFS returning to Malaysia (J. Jawhar, personal communication, December 17, 2019).

\section{A Special Allocation for the Terrorist Deradicalisation Programme}

Insufficient government allocation for deradicalisation modules has adversely affected the existing deradicalisation programme in Malaysia (Z.M. Zin, personal communication, February 12, 2020). This constraint has disrupted the execution of various planned modules. Therefore, a special allocation to ensure smooth implementation of the modules is essential. Alternative ways of raising additional funds through cooperation with NGOs and private firms in Malaysia should be considered.

\section{E. The Political Situation in Malaysia is Exposed to the Risk of Terrorism}

A political science and Islamic studies lecturer of the International Islamic University of Malaysia (IIUM) and member of the Government Deradicalisation Panel explained the following:

The political situation in Malaysia presents new security challenges and dimensions for terrorist threats. This is because Daesh terrorists and FTFS have always claimed that Malaysia has failed to govern the country in accordance to the true principle of "Islamic State". I also look forward to witness any political moves taken by Malaysia as a result of the return of Daesh FTFS. Among others are potential security threats, monitoring processes and deradicalisation programmes that could have major implications for the country's financial resources and disputes over the identity and loyalty issues of Daesh FTFS to Malaysia(Al-Muhammady, personal communication, November 16, 2019).

\section{F. Absence of a Post-Deradicalisation Programme}

Al-Muhammady (personal communication, November 16, 2019) highlighted that the deradicalisation programme in Malaysia needs to be implemented consistently and improved. Z.M. Zin (personal communication, February 12, 2020) concurred with the views of Al-Muhammady (personal communication, November 16, 2019) and explained that the absence of a post-deradicalisation programme could represent a heightened risk of terrorist recidivism. The postderadicalisation programme is vital, as former detainees need constant support on various socioeconomic aspects, covering employment, accommodation, family and community inclusion, etc., once they are released from deradicalisation centres. Psychological counselling must also be part of the post-deradicalisation phase. Unless these aspects are addressed, former detainees would be depressed and unable to survive and re-integrate with the community, which might lead them back to Daesh terrorism (Z.M. Zin, personal communication, February 12, 2020).

\section{G. Human Rights Versus Enforcement}

There has been an increasing demand from Malaysian human rights activists for 39 Malaysian Daesh FTFS living in Syria and Iraq to be sent home and released without being charged (RMP, 2019). Based on Article 15 of the Universal Declaration of Human Rights, Malaysia should not discriminate against Malaysian Daesh FTFS or deprive them of their citizenship rights and should take responsibility to bring them home (Bilkova, 2018). Taking away the Daesh FTFS' citizenship contravenes international law, particularly the 1954 Convention on the Reduction of Statelessness (Bilkova, 2018). This poses a major challenge to the government, especially in managing the return of Daesh FTFS, the security risks, transportation costs and the deradicalisation programme (RMP, 2019).

\subsection{Best Practices of Deradicalisation and Integration Programmes to Emulate}

Constraints in implementing deradicalisation have increased security threats from returning Daesh FTFS, including those of Malaysian origin. It is pertinent for Malaysia to evaluate and improve existing policiesas well as its deradicalisation and integration programme based on the best practices of exemplary countries such as Denmark and Morocco.

\subsubsection{Denmark}

Denmark is an ideal example of a non-Muslim country that has implemented a comprehensive community integration and deradicalisation programme. Danish authorities have pioneered the programme, providing former terrorists and FTFSthe opportunity to reintegrate themselves with mainstream society. Denmark's soft approaches (psychology and public awareness) are considered in tandem with universal human rights,given that European countries face threats from 5,000 Daesh FTFS (Jakobsen, 2018). This programme integrates many parties, including social-service providers, healthcare agencies, the education sector, police and intelligence services, families and local communities. Since 2014, 16 Danish FTFS who returned from Syria and Iraq (out of 143) have been deradicalised and avoided recidivism to terrorist activity (Nunlist, 2017). 
The uniqueness of this programme is the continued government assistance provided to former detainees for seeking employment, psychological and medical treatment after their release and special training by mentors who are former deradicalised terrorists toenable them to rejoin society without facing prejudice (Nunlist, 2017).

Psychological assessments by the Danish authorities continue for three years after the detainees complete the radicalisation and post-deradicalisation programmes, aimed at ensuring that former detainees do not regain their extreme views and radical ideology (Nunlist, 2017). During this period, former detainees who are beset by psychological problems areassisted through close engagement with psychological experts, peers, families and communities, which is organised by the authorities with localNGO assistance. Continuous psychological support through NGOs has not been extensively implemented in Malaysia, posing a security risk if former Daesh detainees revert to their previous radical ideology and plan violent attacks in the country (Z.M. Zin, personal communication, February 12, 2020).

\section{A. The Aarhus Deradicalisation Model}

The first deradicalisation programme in Denmark was launched in 2009 (Jakobsen, 2018). In 2014-2016, a national action plan for preventing and fighting terrorism, extremism and radicalisation was initiated (Jakobsen, 2018), a coordinated effort involving actors of different levels. The government authorities include the Ministry of Justice, Ministry of Children, Education and Equality, Ministry of Foreigners and Integration, Ministry of Social Affairs and Ministry of Foreign Affairs. Actors in the national realm include the National Centre for Prevention of Extremism, the Danish Intelligence Service, Probation Service (Kriminalforsorgen) and others (Jakobsen, 2018). The main goal of the plan and Denmark's efforts is to prevent radicalisation and extremism. The Aarhus Model and Exit Programme (deradicalisation, post-deradicalisation and reintegration) to rehabilitate Daesh FTFS was then introduced in 2016 (Nunlist, 2017).

This model reflects the Danish government's unceasing support for the prevention and deradicalisation mechanisms implemented since the 1970s to deal with left-wing extremism (Nunlist, 2017). It has undergone many improvements since 2014, especially after the emergence of Daesh. In 2016, the Danish Action Plan to Address Terrorism, Extremism and Radicalisation was introduced by the Danish Intelligence Agency (Politiets Efterretningstjeneste-PET) to improve upon the Aarhus Model (PET, 2016).

The Aarhus Model focusses on disengaging and deradicalising terrorists and Daesh FTFS and reintegrating them with the local community (PET, 2016). This process ensures that they can leave the terrorist groups for good, participate in capacity-building initiatives through the programme and finally join the community's integration activities (PET, 2016).

\section{B. The Aarhus Model's Specific Elements}

Bertelsen (2015) outlines seven specific elements of the Aarhus Model that are different from other countries' deradicalisation programmes. First is the infohouse that involves collecting terrorist suspects' personal data. This information is normally shared with the local police by parents, family members, teachers, friends, social workers and law enforcement officers. The police analyse the information received and contact the suspects for further investigation, without any arrests. If the suspects are radical, the process of counselling, deradicalisation and ideological brainwashing is conducted by the local municipal council with assistance from the police. Second, the Mentor Program involves 10 psychologists specialising in issues of terrorism, counselling and rehabilitation of former prisoners (Bertelsen, 2015). These psychologists specialise in deradicalisation and provide counselling and psychological support for identified suspects to share past experiences. Psychological assessment is also conducted on an ongoing basis, even if the offenders have recovered and completed the deradicalisation programme. Third, periodical workshops on public awareness and prevention of radicalisation are organised at schools, universities and workplaces.

Fourth, the Parents Network in Denmark deals with teenagers or children with radical views. Involving parents in the daily operations is unique to the Aarhus Model; this is not implemented in most countries, including Malaysia. Fifth, the Inter-Faith Dialogues group aims at educating the public to respect religious similarities, differences and cultural diversity in Denmark (Bertelsen, 2015). Sixth, self-development skills training is provided to all staff and community members involved in operating the Aarhus model. Seventh, the Exit Program is specifically developed for Daesh FTFS to return and integrate with the community. In the post deradicalisation programme, former detainees are assisted in seeking employment, education, housing, counselling, and psychological and medical treatment, to ensure that they can lead a new life normally (Bertelsen, 2015). 
In contrast, a similar approach is not practiced in Malaysia, and there is no follow up on former detainees who have been released (Z.M. Zin, personal communication, February 12, 2020).In the Aarhus Model, individuals are only given assistance after they have passed the security clearance and are no longer a threat (Nunlist, 2017).

\section{Government, NGO and Community Engagement in Denmark's Post-DeradicalisationProgramme}

Various Danish ministries are involved in the deradicalisation programme, including the Ministry of Law, Ministry of Children, Education and Equality, Ministry of Foreign Works and Integration, Ministry of Social Affairs and the Foreign Ministry (PET, 2016). Meanwhile, at the agency level, Denmark has established the Centre for Prevention of Extremism (preventing extremism and conducting deradicalisation) and the kriminalforsorgen Centre (implementing post-deradicalisation), which work closely with PET (PET, 2016). Police, local authorities, municipalities and educational institutions in 12 districts and 98 municipalities across Denmark are also involved in this initiative (PET, 2016), whereas schools are hardly involved in Malaysia's deradicalisation programme. In addition, there is close and open collaboration between the government and local groups supporting the Kriminalforsagen (PET, 2016) programme. For example, the Youth to Youth NGO communicates with teenagers to raise awareness of the dangers of terrorism, as they are most vulnerable to radicalisation. Meanwhile, the Back to Work NGO assists former Daesh detainees to find employment and financial resources. Penalising Daesh FTFS in prison without any de-radicalisation and post-deradicalisation only aggravates the situation, as they could become more violent and also radicalise other offenders (Nunlist, 2017).

\subsubsection{Morocco}

Morocco, an Islamic country, has a Daesh FTFS deradicalisation and integration programme unique in the Middle East (Berrada, 2019). Morocco's approach emphasises strengthening security agencies' assets, the deradicalisation programme and engagement between security agencies and former detainees to address the return of Daesh FTFSas well as on the reintegration of former Daesh FTFS through community-based activities (Berrada, 2019). Around 5,000 Moroccan FTFS have travelled to Syria and Iraq, with 2,000 joining the conflict in Libya (Berrada, 2019). Berrada (2019) asserted that the Arab Spring was the trigger that drove many Moroccans towards Daesh.

\section{A. The Moussalaha Deradicalisation Model}

Morocco's security measures have been relatively effective in preventing major terrorist attacks in recent years. The country began a more systematic approach of integrating terrorists into mainstream society in 2016. The General Delegation for Prison Administration and Reintegration (DGAPR) launched the Moussalaha (reconciliation) deradicalisation programme in prisons together with the Mohammedia League for Scholars (RABITA) and the National Council for Human Rights (CNDH). The programme aims to counter the Salafi-Jihadi ideology of Daesh FTFS in Moroccan detention centres by adopting reconciliation through self, religious texts and community integration (Berrada, 2019, p. 32).

\section{B. Specific Elements of the Moussalaha Programme}

Key elements incorporated into the Moussalaha Programme are denouncing violence and terrorism, recognising the diversity of religions and upholding Morocco's monarchy (Berrada, 2019). There is a shift in the way Moroccan authorities handle terrorism, evolving from a purely security-led approach to one of deradicalisation and reintegration. The Moussalaha Programme encourages former Daesh FTFS to enrol in a voluntary deradicalisation initiative that enables them to receive royal pardon based on their recovery. In July 2019, 25 terrorist offenders were pardoned, which encouraged over 200 other detainees to denounce their radical ideology to fully recover (Berrada, 2019).

Morocco's Ministry of Islamic Affairs and RABITA also play a significant role in revising the way Islam is taught and interpreted, thereby addressing misinterpretations of Islam by returning Daesh FTFS (Guessous, 2019). At the same time, the Moroccan government also conducts awareness campaigns through multiple media platforms including television, government social media sites, radio, online comics, video games, youth programmes and activities. Crossgender psychological engagements (female experts for male offenders and vice versa) are also practiced. As a result, 12.5\% of 200 Daesh FTFS who returned to Morocco were successfully deradicalised as of December 2019 (Guessous, 2019).

\section{Government, NGO and Community Engagement in Morocco's Post-Deradicalisation Programme}

The Moussalaha Deradicalisation programme is comprehensive. It not only targets preventing terrorist attacks but addresses the root causes of radicalisation, such as socioeconomic and ideological imbalances (Berrada, 2019). Apart from the Ministry of Islamic Affairs, the Ministry of Home Affairs and the DGAPR, collaboration with NGOs such as RABITA and CNDH has been intensified. 
Unlike in Morocco, cooperation between the government and NGOs in the Malaysian context has not been encouraging. Malaysian NGO activities are constantly monitored by the RMP, especially those involved in humanitarian missions to Syria and might have links with Daesh. Morocco's approach should be emulated by Malaysia, as NGOs may have more resources, funds, manpower and networks that can be utilised (Al-Muhammady, personal communication, November 16, 2019).

Moreover, the King Mohammed VI Fund was also created to support the recovery, deradicalisation, postderadicalisation and community integration of Daesh FTFS in Morocco (Hatim, 2020). These funds provide ongoing financial support to former detainees in the aspects of social engagement, health, family management, education and professional support after completing the Moussalaha programme (Hatim, 2020). Toboost their confidence, former Daesh detainees who have formed their own NGOs are engaged to assist the deradicalisation programme pioneered by the government (Guessous, 2019). This is crucial to building confidence among the former Daesh FTFS and persuading them to get enrolled in the government's programme. These NGOs also assist with integrating former terrorists into the community.

\subsection{Recommended Improvements to Malaysia's Deradicalisation Programmes}

A comparative analysisof Malaysia, Denmark and Moroccois important to gain a balanced perspective of non-Muslim and Muslim countries' deradicalisation programmes, as the latter have been international role models.

Malaysia's POTA Integrated Deradicalisation Programme for Daesh FTFS has received international acclaim, but there is room for improvement. The critical assessment in previous sections shows that Malaysia's deradicalisation programme is less focused on the aspects of psychology, cooperation between the government and NGOs, postderadicalisation and reintegration of Daesh FTFS (Table 1). As already elaborated, Denmark and Morocco emphasise these aspects. Based on the analysis, some recommendations are provided below to improve the Daesh FTF deradicalisation and integration modules in Malaysia.

\subsubsection{Establishing a Post-Deradicalisation Programme for Daesh FTFS}

The existing deradicalisation modules in Malaysia do not include a post-deradicalisation programme. The postderadicalisation period is critical to ensure that former detainees can adapt and integrate themselves with the social environment and local community with guidance and assistance from the government and public. As implemented in Denmark and Morocco, Malaysia needs to ensure that its post-deradicalisation programme considers self-development, employment assistance, housing, education, financial aid, counselling and psychological, and medical services (Table 1)to enable former detainees to rebuild their lives. This would follow Morocco's example of providing housing assistance to the impoverished; as poverty perpetuates terrorism while the socioeconomic conditions of terrorists must be addressed (Aziza, 2018). Therefore, the programmemust emphasise these aspects.

\subsubsection{Empowerment of the Psychological Officers and Services}

In Malaysia, some psychologists and invited speakers are not trained to address terrorism and change the radical mindset. Further, they are frequently transferred for various reasons (Z.M. Zin, personal communication, February 12, 2020). This leads to failure in the implementation of the psychological module and affects the overall POTA terrorist rehabilitation (Z.M. Zin, personal communication, February 12, 2020). To overcome this, a dedicated deradicalisation unit comprising of trained psychologists with at least diplomas in counselling and specially trained to handle terrorists should be formed, and they should not be transferred to other departments or ministries. This dedicated unit is to ensure that the psychological module achieves its main objective of weakening the former FTFS' radical ideology. Refresher courses and continuous psychological assessments must be conducted to ensure no recidivism to terrorism occurs. Moreover, cooperation between local and foreign psychologists needs to be strengthened to permit sharing of best practices between countries.

\subsubsection{Special Financial Allocation for the Deradicalisation Programme}

The less than adequate financial allocation for the terrorist deradicalisation programme in Malaysia impacts its effectiveness. Special funds should be made available and not shared with commercial offenders' rehabilitation programmes. This special financial allocation for the terrorist deradicalisation programme, specifically for former Daesh FTFS, is essential to ensure that all the planned modulescan be implemented (Z.M. Zin, personal communication, February 12, 2020).In the case of Denmark and Morocco, special funds were provided to facilitate post-deradicalisation programmes and integration of Daesh FTFS into the community with NGO assistance. This indicates that countries with special financial allocations for deradicalisation programmes focus on their efforts to combat radicalisation and terrorism. 


\subsubsection{Enhance Collaboration with NGOs and Government-Linked Companies in Supporting the Government Deradicalisation Programme}

The Malaysian government, the main driver of the deradicalisation programme, will need to identify the role that NGOs, government-linked companies (GLCs) and multinational companies (MNCs) can play in making the programme successful. As highlighted earlier, the government has no specific financial allocation for the deradicalisation programme. Denmark and Morocco realised their financial constraintsand increased their cooperation with NGOs. Malaysia must work with more NGOs and possibly GLCs and MNCs to obtain additional funding and expertise. Apart from Ahli Sunnah Wal Jamaah (ASWAJA), which has been in close cooperation with the RMP, other reputable NGOs such as the Majlis Perundingan Pertubuhan Islam Malaysia (MAPIM), Yayasan Dakwah Islam Malaysia (YADIM), Persatuan Gerakan Kemanusiaan Malaysia (MyHumanitarian) and Pertubuhan Penggerak Masyarakat Malaysia (PENGGERAK) are among the NGOs that can potentially assist the government in community activities and creating employment opportunities and skills for former Daesh FTFS. These NGOs possess solid reputations, influence and networks not only in Malaysia but around the globe (Z.M. Zin, personal communication, February 12, 2020).Malaysia is just beginning to form linkages with NGOs in assisting with its deradicalisation programme,confirming Suratman's (2017) view that Southeast Asian countries are just beginning to see the benefits of collaborating with NGOs given their own limited human resource training and funding.

Further, the government can initiate cooperation with private companies, GLCs and MNCs to get funding and employment assistance for former Daesh FTF detainees after their release, which can reduce the government's financial burden. These job opportunities can help reduce recidivism and elevate their confidence to return to society. Additionally, educational assistance can also be provided through special loans or scholarships for them to study in certain fields. To date, no private firm has been involved in such a partnership in Malaysia. This goes beyond obtaining the help of NGOs, as previously highlighted by Suratman (2017), and there are clear benefits of collaborating with MNCs and GLCs who can provide funding that NGOs may not be ableto,thereby fulfilling their corporate social responsibility (CSR) goals. Therefore, cooperation between private companies, GLCs and MNCs for Malaysia's deradicalisation programme can help supplement the government funds.

Figure 1 shows the Deradicalisation Stakeholder Model created in this study, which explains how cooperation between governments, NGOs and private companies (GLCs and MNCs) should go about addressing issues of government financial allocation, employment, education opportunities and capacity building. The government is the key driver, which comprises of the MOHA, RMP, the Malaysian Prison Department, JAKIM and the Department of Social Welfare; the five main NGOs proposed include ASWAJA, MAPIM, YADIM, MyHumanitarian and MYGERAKAN; while private companies, GLCs and MNCs work in collaboration with the other actors. Thus, a hybrid approach to the deradicalisation programme in Malaysia can be implemented in collaboration with these three key actors.

\subsubsection{Appointing External Panellists to Assess the Effectiveness of the Existing Deradicalisation Programme}

There is a need to re-evaluate Malaysia's way of measuring a $97.5 \%$ success rate for the deradicalisation programme ("Zahid: Deradicalisation," 2017). This is because some hardcore terrorists may have gone back to terrorism. This reduces the percentage mentioned above. Further, the involvement of government officials may have contributed to the bias in assessing the success of the deradicalisation programme. The appointment of external panellists and observers can help monitor whether the implemented procedures align with international practices. Moreover, the involvement of international bodies such as the United Nations Security Council (UNSC), Association of Southeast Asian Nations Counter-Terrorism Committee (ASEAN CTC) and overseas NGOs is also important, as they can provide additional critical viewpoints and suggestions to improve the deradicalisation and integration programmes in Malaysia.

\subsubsection{An Effective Monitoring Mechanism in the Post-Deradicalisation Period}

In the post-deradicalisation period, the role of families and local communities is important in preventing any relapse among former detainees. The trust cultivated between former detainees and their families is essential to ensure their effective integration into the community. Engagement with the community should be strengthened without any provocation or negative sentiment against the former detainees to prevent recidivism into terrorism. The extreme stigma against former FTFS and Daesh terrorists should be assuaged by giving them a second chance to repent and return to the mainstream. In this regard, Malaysian NGOs can emulate the proactive role played by NGOs in Denmark and Morocco. In Denmark, the Youth to Youth NGO approaches highly susceptible youth to explain the dangers of joining Daesh, while Back to Workhelps deradicalised Daesh FTFS find suitable jobs and provides financial startups(Table 1). 
In Morocco, NGOs such as RABITA and CNDH have been effective in monitoring the activities of former detainees, as they share any progress with the government (Table 1).

\subsubsection{Government Awareness Campaigns and Promotions in Combatting Daesh}

To date, Malaysia has implemented various strategies and security measures to curb Daesh activities and the returning FTFS, but those initiatives were not disclosed by the authorities because of confidentiality and covert operations. There is a need to intensify public awareness campaigns on terrorism, as conducted by Morocco, through television, government social media sites, radio, comics, video games and peer programmes targeting youth groups (Aziza, 2018; Berrada, 2019). This can serve as a double-edged strategy because it can promote the government's success in addressing the threat from Daesh FTFS while simultaneously warning the public about the dangers of joining Daesh.

\section{Conclusion}

This study aimed to analyse the current implementation of Malaysia's deradicalisation policies and programmes, which can be improved through emulating some of the best practices of Denmark and Morocco. The results indicate that the Malaysian deradicalisation programme is deficient when compared to Denmark and Morocco. It lacks psychological expertise, NGO involvement, post-deradicalisation and integration of Daesh FTFS into the mainstream. Malaysia will need to incorporate these aspects from Denmark and Morocco's deradicalisation programmes to leave no room for recidivism among former Daesh FTFS. Malaysia also needs a specific budget allocation only for the deradicalisation programme, which must not to be shared with other offender rehabilitation programmes. Intensifying Malaysia's public awareness campaign on the evils of terrorism by targeting youth through diverse media and social media networks is also crucial learning from the experience of Morocco. Future studies concerning deradicalisation in Malaysia should focus on other countries beyond the Southeast Asian region because there is still much to be learned from their practices.

\section{Acknowledgements}

The authors wish to thank the anonymous reviewers for their constructive comments.

Disclaimer

The views and opinions expressed in this study are those of the authors and do not necessarily reflect the official policy or position of the organisation they represent.

\section{References}

Abbot, K.W. \& Snidal, D. (2009). Strengthening international regulation through transnational new governance overcoming the orchestration deficit. Vanderbilt Journal of Transnational Law,42 (2), 501-78.

Aziza, B. (2018, December 21). Morocco's unique approach to countering violent extremism and terrorism. Small Wars Journal. https://smallwarsjournal.com/jrnl/art/moroccos-unique-approach-countering-violent-extremismand-terrorism.

Berrada, K. K. (2019). Morocco's response to returning foreign terrorist fighters: Tighter security and deradicalisation. Egmont,107(2), 23-35.

Bertelsen, P. (2015). Danish preventive measures and deradicalisation strategies: The Aarhus model. Insights into Asian and European Affairs21(2), 241-253.

Bilkova, V. (2018).Foreign terrorist fighters and international law. Groningen Journal of International Law,6(1), 1-23.

Feldstein, M. (2015). Into the fold: Evaluating different countries' programmes to deradicalise Islamic extremists and Islamist terrorists. John Hopkins University.

Guessous, H. (2019, May 1). Abdellah Boussouf: Morocco's stability is due to its model of religiosity. Morocco World News. https://www.moroccoworldnews.com/2019/05 /271971/abdellah-boussouf-morocco-stability-religiosity/

Hatim, Y. (2020, February 6). Moroccan foundation celebrates release of 10 former extremists. Morocco World News. https://www.moroccoworldnews.com/2020 /02/292988/moroccan-foundation-celebrates-release-of-10-formerextremists/

Jakobsen, H.H. (2018). Returning foreign fighters: The case of Denmark. International Review of the Red Cross, $100(1), 315-336$.

Kamaruddin, M.N., Noordin, N.N.M., \& Rahman, A.R.A. (2017). Terrorist deradicalisation programme in Malaysia: A case study. Journal of Media and Information Warfare, 10, 25-49.

Levenia, U. \& Sciascia, A. (2020, October 3). Does Indonesia's deradicalisation program work? The Diplomat: https://thediplomat.com/2020/06/does-indonesias-deradicalisation-program-work/. 
Mabborang, V.B. (2019). Assessing the effectiveness of the Philippines de-radicalisation program. (Master's thesis, US Army Command and General Staff College, Fort Leavenworth, Kansas, United States), Retrieved fromhttps://apps.dtic.mil/sti/pdfs/AD1105123.pdf.

Ministry of Home Affairs of Malaysia (MOHA). (2015). Integrated deradicalisation module for terrorists. Pencetakan Mesbah.

Nunlist, C. (2017). Dealing with jihadist returnees: A tough challenge. CSS Review \& Analyses, 1(2), 1-4.

Politiets Efterretningstjeneste (PET). (2016). Threat assessment:Terror threats against Denmark from individuals travelling to Syria/Iraq. PET.

Royal Malaysian Police (RMP). (2019). Daesh threats assessment and statistics, August 2019. RMP.

Suratman, Y. P. (2017). The effectiveness of de-radicalisation program in Southeast Asia: Does it work? The case of Indonesia, Malaysia, and Singapore. Journal of ASEAN Studies,5(2), 135-56.

United Nations. (2008). First report of the working group on radicalisation and extremism that lead to terrorism: Inventory of state programmes.UNHCR.

Walanda, G. (2020). The path to sustainable deradicalisation program. Journal of Terrorism Studies,2(1), 1-28. https://doi.org/10.7454/jts.v2i1.1017.

Zahid: Deradicalisation programme has 97.5pct success rate. (2017, February 20).Malaysiakini. https://www.malaysiakini.com/news/373066.

\section{Tables and Figures}

\section{Table 1: A Comparison of Deradicalisation Programmes in Malaysia, Denmark and Morocco}

\begin{tabular}{|c|c|c|}
\hline & & \\
\hline \multicolumn{3}{|c|}{ About the Deradicalisation Module } \\
\hline $\begin{array}{l}\text { - The Prevention of Terrorism Act } 2015 \\
\text { (POTA) Prisoner Integrated Recovery } \\
\text { Module. } \\
\text { - Introduced in } 2015 \text {. } \\
\text { - Spearheaded by the Public Order } \\
\text { Division, Ministry of Home Affairs, } \\
\text { Royal Malaysian Police and Malaysian } \\
\text { Prisons Department. } \\
\text { - Cooperation between Department of } \\
\text { Islamic Development Malaysia } \\
\text { (JAKIM), National Security Council, } \\
\text { Ministry of Women, Family \& } \\
\text { Community Development. }\end{array}$ & $\begin{array}{l}\text { - Aarhus model. } \\
\text { - The module was introduced in } \\
2009 \text { and improved in } 2014 \text { and } \\
2016 \text {. } \\
\text { - Led by the Ministry of Justice and } \\
\text { the Ministry of Children, } \\
\text { Education and Equality. } \\
\text { - Involves cooperation with the } \\
\text { Ministry of Foreigners and } \\
\text { Integration, the Ministry of Social } \\
\text { Affairs and the Ministry of } \\
\text { Foreign Affairs. }\end{array}$ & $\begin{array}{l}\text { - Moussalaha Programme. } \\
\text { - Introduced in } 2016 . \\
\text { - Led by the Ministry of Islamic } \\
\text { Affairs and the Moroccan Prisons } \\
\text { and the General Delegation for } \\
\text { Prison Administration and } \\
\text { Reintegration (DGAPR). } \\
\text { - Setting up of the King Mohammed } \\
\text { VI special fund for deradicalisation, } \\
\text { post-deradicalisation and integration } \\
\text { of terrorists into society. }\end{array}$ \\
\hline \multicolumn{3}{|c|}{ Programme Focus } \\
\hline $\begin{array}{l}\text { - Focus on deradicalisation to correct } \\
\text { militant distorted ideology. } \\
\text { - Uses religion, psychology, security, } \\
\text { nationhood, and pure values in the } \\
\text { syllabus. } \\
\text { - Not much focus on the post- } \\
\text { deradicalisation aspect, especially on } \\
\text { integration and acceptance into society, } \\
\text { because of limited funding. }\end{array}$ & $\begin{array}{l}\text { - Emphasis on the post- } \\
\text { deradicalisation process and } \\
\text { terrorists' integration into } \\
\text { society. } \\
\text { - Uses elements of the InfoHouse, } \\
\text { periodic workshops, parent } \\
\text { networks, interfaith dialogue and } \\
\text { outreach programs. }\end{array}$ & $\begin{array}{l}\text { deradicalisation, post- } \\
\text { lisation and community } \\
\text { on. } \\
\text { condemns violence and } \\
\text { n, recognises the diversity } \\
\text { ous sects and upholds the } \\
\text { nty of the Moroccan } \\
\text { ical system. }\end{array}$ \\
\hline \multicolumn{3}{|c|}{ Cooperation with Non-Governmental Organisations and Society } \\
\hline $\begin{array}{l}\text { - Cooperation only with the Association } \\
\text { of the Ahli Sunnah Wal Jamaah } \\
\text { Organization (ASWAJA). } \\
\text { - Financial constraints led to the } \\
\text { termination of cooperation in June } 2018 \text {. } \\
\text { - Confidentiality of information and a less } \\
\text { open approach are factors that cause the } \\
\text { lack of cooperation with NGOs. }\end{array}$ & $\begin{array}{l}\text { - Very close and open cooperation } \\
\text { between the government and non- } \\
\text { governmental organisations } \\
\text { (NGOs) to support the } \\
\text { Kriminalforsagen (post- } \\
\text { deradicalisation) programme. } \\
\text { - The Youth to Youth NGO } \\
\text { reaches out to teenagers and } \\
\text { explains the dangers of terrorism. }\end{array}$ & $\begin{array}{l}\text { - Cooperation with NGOs such as } \\
\text { RABITA and CNDH has been } \\
\text { implemented for the country's post- } \\
\text { deradicalisation program. } \\
\text { - The King Mohammed VI fund has a } \\
\text { special allocation for } \\
\text { deradicalisation, and post- } \\
\text { deradicalisation and terrorists' } \\
\text { integration programmes into society } \\
\text { which can be used by the NGOs }\end{array}$ \\
\hline
\end{tabular}




\begin{tabular}{|c|c|c|}
\hline Malaysia & Denmark & Morocco \\
\hline \multicolumn{3}{|c|}{ Cooperation with Non-Governmental Organisations and Society } \\
\hline & $\begin{array}{l}\text { - The NGO Back To Work helps } \\
\text { former foreign fighters get jobs } \\
\text { and integrates them into society. }\end{array}$ & $\begin{array}{l}\text { involved. } \\
\text { Builds the confidence of Daesh } \\
\text { offenders to recover. }\end{array}$ \\
\hline \multicolumn{3}{|c|}{ Mentor Programme } \\
\hline $\begin{array}{l}\text { - Uses the services of former terrorists } \\
\text { detained under the International } \\
\text { Security Act } 1960 \text { as facilitators for the } \\
\text { deradicalisation programme. } \\
\text { - The counsellors are not specifically } \\
\text { trained with a psychology diploma but } \\
\text { on the Islamic religion. }\end{array}$ & $\begin{array}{l}\text { - Uses the services of } 10 \\
\text { psychologists, counsellors and } \\
\text { former detainees who have } \\
\text { recovered. } \\
\text { - Provides counselling, } \\
\text { psychological services and } \\
\text { stresses on certain important } \\
\text { aspects to return to the } \\
\text { community. }\end{array}$ & $\begin{array}{l}\text { - Uses the services of former Daesh } \\
\text { terrorists for the deradicalisation } \\
\text { programme such as Abdelkerim } \\
\text { Chadli and Mohamed Rafiki Abu } \\
\text { Hafs who have set up their own } \\
\text { NGOs assisted by the government. }\end{array}$ \\
\hline \multicolumn{3}{|c|}{ Integration Process in Society } \\
\hline $\begin{array}{l}\text { - The absence of a post-deradicalisation } \\
\text { programme complicates the reintegration } \\
\text { of terrorists into society, which also } \\
\text { lacks cooperation with NGOs. } \\
\text { - Does not provide any financial } \\
\text { incentives for the former terrorists to } \\
\text { start life anew. } \\
\text { - Does provide some vocational training } \\
\text { while terrorists are in jail to enable them } \\
\text { to hunt for employment once they are } \\
\text { released. }\end{array}$ & $\begin{array}{l}\text { - The Kriminalforsagen (post- } \\
\text { deradicalisation) programme } \\
\text { allows the integration process to } \\
\text { be implemented. }\end{array}$ & $\begin{array}{l}\text { - Cooperation with NGOs such as } \\
\text { RABITA and CNDH has been } \\
\text { implemented for the country's post- } \\
\text { deradicalisation program } \\
\text { - Does provide housing assistance for } \\
\text { those disfranchised in society, such } \\
\text { as terrorists. }\end{array}$ \\
\hline
\end{tabular}




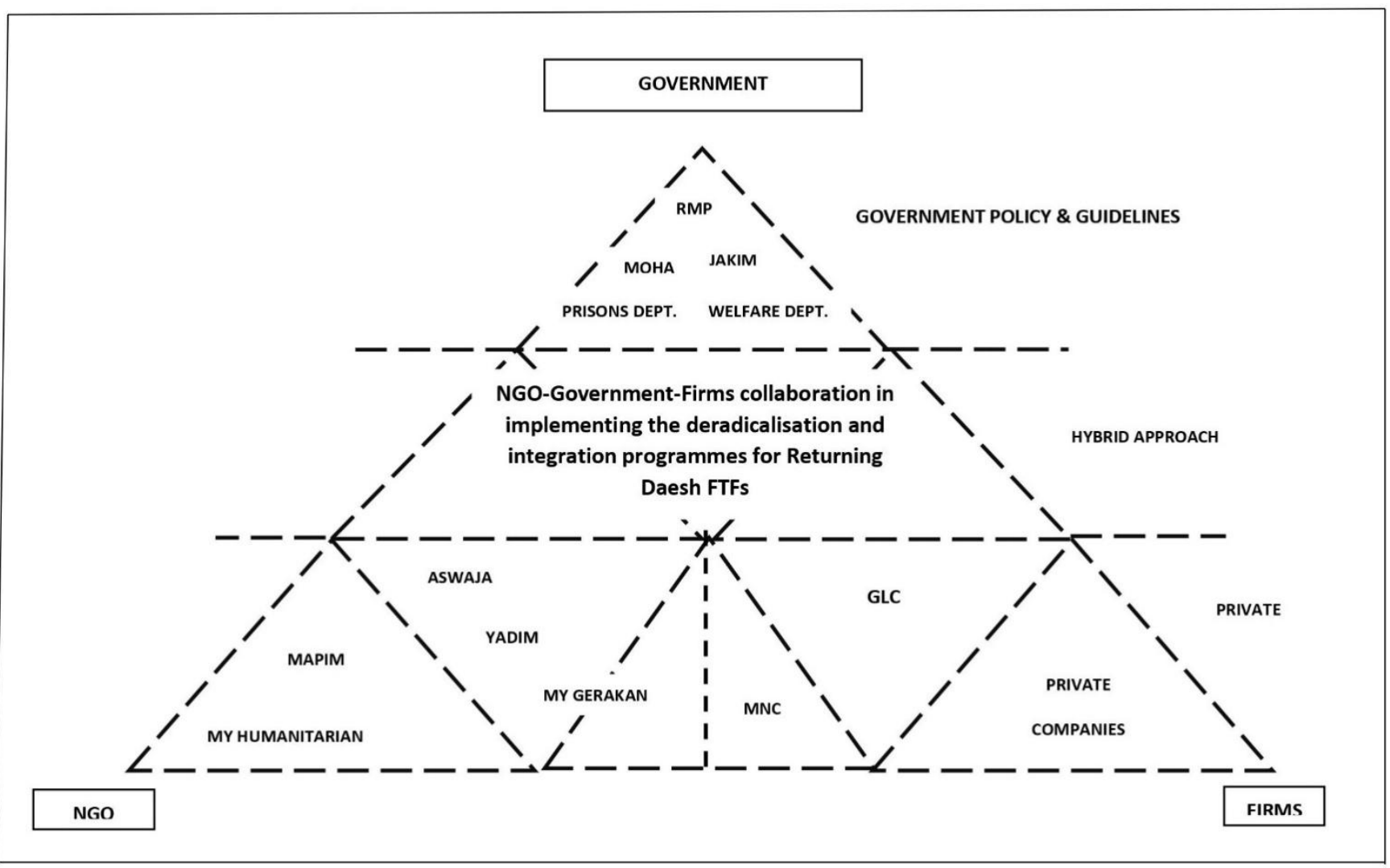

Figure1: The Deradicalisation Stakeholder Model,adapted from Abbot and Snidal (2009) 